\title{
Binding of Uropathogenic Escherichia coli R45 to Glycolipids Extracted from Vaginal Epithelial Cells Is Dependent on Histo-Blood Group Secretor Status
}

\author{
Ann Stapleton, * Edward Nudelman, ${ }^{*}$ Henrik Clausen, ${ }^{5}$ Sen-itiroh Hakomori, ${ }^{\star}$ and Walter E. Stamm* \\ ${ }^{*}$ Department of Medicine, University of Washington, Seattle, Washington 98195; ${ }^{\ddagger}$ The Biomembrane Institute, Seattle, Washington \\ 98119; and ${ }^{\S}$ Department of Oral Diagnosis, The Royal Dental College, Copenhagen, Denmark
}

\begin{abstract}
Women with a history of recurrent Escherichia coli urinary tract infections (UTIs) are two to three times more likely to be nonsecretors of histo-blood group antigens than are women without such a history. Further, uroepithelial cells from women who are nonsecretors show enhanced adherence of uropathogenic $E$. coli compared with cells from secretors. To investigate the hypothesis that nonsecretors express unique receptors for uropathogenic $E$. coli related to their genetic background, we extracted glycosphingolipids (GSLs) from vaginal epithelial cells collected from nonsecretors and secretors and used an assay in which radiolabeled uropathogenic $E$. coli were bound to these GSLs separated on TLC plates. An $E$. coli strain (R45) expressing both $P$ and $F$ adhesins, which was isolated from one of these patients' UTIs, was metabolically labeled with ${ }^{35} \mathrm{~S}$ for the TLC binding assay. The radiolabeled $E$. coli R45 bound to two extended globo-series GSLs, sialosyl gal-globoside (SGG) and disialosyl gal-globoside (DSGG), found in the GSL extracts from nonsecretors but not from secretors. The identity of SGG in the nonsecretor GSL extracts was confirmed in radioimmunoassays using an mAb to SGG and in immunofluorescence assays with this $\mathrm{mAb}$ and native vaginal epithelial cells. We show that SGG and DSGG are selectively expressed by epithelial cells of nonsecretors, presumably as a result of sialylation of the gal-globoside precursor glycolipid, which in secretors is fucosylated and processed to $\mathrm{ABH}$ antigens. The presence of SGG and DSGG may account for the increased binding of $E$. coli to uroepithelial cells from nonsecretors and for their increased susceptibility to recurrent UTI. (J. Clin. Invest. 1992. 90:965-972.) Key words: recurrent urinary tract infection • nonsecretor • glycosphingolipid receptors
\end{abstract}

\section{Introduction}

Acute uncomplicated urinary tract infections (UTIs) ${ }^{1}$ occur in millions of young women each year. Although most of these

Portions of this work were presented at the annual meeting of the Association of American Physicians/American Society for Clinical Investigation/American Federation of Clinical Research, May 1991, and have been published as an abstract (1991. Clin. Res. 39:214a).

Address correspondence to Dr. Ann Stapleton, Department of Medicine, Harborview Medical Center, 325 Ninth Avenue, ZA-89, Seattle, WA 98104.

Received for publication 22 October 1991 and in revised form 16 March 1992.

1. Abbreviations used in this paper: DSGG, disialosyl gal-globoside; GSL, glycosphingolipid; HPTLC, high-performance thin-layer chroma-

J. Clin. Invest.

(C) The American Society for Clinical Investigation, Inc.

0021-9738/92/09/0965/08 \$2.00

Volume 90, September 1992, 965-972 women experience only single or sporadic infections, $\sim 20 \%$ suffer very frequent (three or more per year) recurrences (1). The apparent increased susceptibility to UTI in these patients cannot be explained by underlying functional or anatomic abnormalities of the urinary tract, but instead appears to arise from the interaction of infecting Escherichia coli strains with these patients' epithelial cells. Thus, women prone to frequent recurrences demonstrate prolonged colonization of the vaginal mucosa with $E$. coli, the predominant causative species in these infections (2) and threefold more $E$. coli adhere to vaginal, buccal, and uroepithelial cells from women with recurrent UTI than to cells from control patients $(3,4)$. Women with a history of recurrent UTI are also more likely to be nonsecretors of histo-blood group antigens than are women without a history of infections (relative risk $=3-4$ [5-8]), and $E$. coli adhere in greater numbers to uroepithelial cells from nonsecretors (8).

E. coli adhesins also play an important role in the pathogenesis of UTI (9-20), particularly the genetically related P and F adhesins. $\mathrm{P}$ adhesins are present in $50-65 \%$ of $E$. coli strains causing cystitis (9-13) and 75-90\% of isolates from pyelonephritis (10,11, 14-19). The minimal receptor for the $P$ adhesin is the galactose $\alpha 1-4$ galactose moiety, present in the globo-series glycolipids and the $P_{1}$ blood group antigen (20-28). F adhesins are expressed in $30-65 \%$ of UTI isolates $(9,10)$. The minimal binding moiety for the $\mathrm{F}$ adhesin is less well defined and probably more complex; proposed receptors include the Forssman and para-Forssman antigens, globoside, galactosyl globoside, globo-A, and globo-H, and stage-specific embryonic antigen-4 (29-32). The globo-series glycolipids have recently been shown to be modified by the histo-blood group status, and $\mathrm{ABH}$ active globo-series glycosphingolipids (GSLs) are found in renal epithelium and in voided uroepithelial cells as well as on erythrocytes $(21,28,33-38)$.

Given the foregoing, we hypothesized that one explanation for the increased risk of UTI in nonsecretors and for the increased attachment of uropathogenic bacteria to their uroepithelial cells might be the presence of unique receptors for Pand F-fimbriated $E$. coli in such patients. To evaluate this hypothesis, we studied binding of radiolabeled uropathogenic $E$. coli R45 to GSLs extracted from the vaginal epithelial cells of young women of known secretor status and separated on TLC $(39,40)$. We demonstrated binding moieties unique to nonsecretors with structures consistent with $\mathrm{Se}$ gene-mediated control of antigen expression in globo-series GSLs from vaginal epithelial cells.

\section{Methods}

Preparation of glycolipids. Vaginal epithelial cells were collected from healthy female college students whose secretor statuses were deter-

tography; IHW, isopropanol/hexane/water; SGG, sialosyl gal-globoside; UTI, urinary tract infection. 
mined using saliva hemagglutination inhibition assays and whose red blood cell Lewis ${ }^{a}$ antigen phenotypes were determined using hemagglutination assays with an antibody to the Lewis ${ }^{a}$ antigen (7). Cells were collected by saline rinsing and gentle scraping with a spatula, washed four times in PBS, pH 7.3, and stored in a freezing medium (85\% M199 [Sigma Chemical Co., St. Louis, MO], 10\% fetal calf serum, 5\% DMSO) at $-70^{\circ} \mathrm{C}$ until use $(7,41)$. Before glycolipid extraction, the cells were washed four times in PBS, quantitated in a hemocytometer, and equalized for extraction procedures. The cells constituted a homogeneous population possessing typical morphology as viewed on light microscopy. $6-8 \times 10^{7}$ cells pooled from multiple patients or $10^{7}$ cells/ individual patient were used in each TLC assay. The total upper- and lower-phase glycolipid fractions were obtained as follows: cells were extracted twice with $10 \mathrm{vol}$ isopropanol/hexane/water (IHW) (55:25:20 by vol) with sonication in a warm bath and centrifugation at $2,500 \mathrm{rpm}$ for $10 \mathrm{~min}$. The combined supernatant fractions were dried under nitrogen and twice resuspended in chloroform/methanol ( $2: 1$ by vol) with $0.166 \mathrm{vol}$ water and centrifuged at $500 \mathrm{~g}$ for $10 \mathrm{~min}(42)$. Total upper and lower phases were evaporated under a nitrogen stream and resuspended in IHW for chromatography.

For separation of total upper neutral glycolipids and gangliosides, upper phase glycolipids were first resuspended in $0.1 \% \mathrm{KCl}$ in water, subjected to C18 Sep-Pak reverse-phase column chromatography, washed with water, eluted with methanol, dried, and passed over a DEAE Sephadex A-25 column. Gangliosides were then eluted with $0.45 \mathrm{M}$ ammonium acetate in methanol, dried, and passed over a $\mathrm{C} 18$ column.

Glycolipids were preparatively separated by chromatography on glass high-performance thin-layer chromatography (HPTLC) plates (Whatman Inc., Clifton, $\mathrm{NJ}$ ) in chloroform/methanol/water 50:40:10 with $0.05 \% \mathrm{CaCl}_{2}$. The bands were visualized with primuline (43) under ultraviolet (UV) light, marked with a pencil, scraped from the silica plates, extracted twice in IHW, and dried. Glycolipid standards were isolated previously in this laboratory $(38,44-48)$. To generate sialosyl gal-globoside (SGG), disialosyl gal-globoside (DSGG) standard was partially desialylated with $1 \%$ acetic acid at $100^{\circ} \mathrm{C}$ for 5-10 min.

Bacterial labeling. E. coli R45 was isolated from a woman with cystitis and has the pap family genotype, expressing both the P and $F$ adhesins (9). Organisms were kept frozen in $50 \%$ glycerol $/ 50 \%$ Luria broth (49) at $-70^{\circ} \mathrm{C}$ until the night before use, when they were streaked onto Luria agar plates (49) to promote fimbrial expression and grown overnight at $37^{\circ} \mathrm{C}$. On the day of use, bacteria were scraped from the plate, resuspended in M9 medium (49) without amino acids, and shaken at $37^{\circ} \mathrm{C}$ for $40 \mathrm{~min}$ to deplete cellular methionine stores. $\left[{ }^{35} \mathrm{~S}\right.$ ] Methionine (Trans ${ }^{35} \mathrm{~S}$-label, $1137 \mathrm{Ci} / \mathrm{mmol}$, ICN Biochemicals, Irvine, $\mathrm{CA}$ ) was then added at $200 \mu \mathrm{Ci} / 10^{10}$ organisms, the cells were shaken for $1 \mathrm{~h}$, washed three times in PBS and resuspended in PBS ( $\mathrm{pH}$ 7.3), and counted in a scintillation counter to give a final activity of $\sim 0.01-0.02 \mathrm{cpm}$ per organism.

Bacterial overlay assays. Glycolipids (10-40 $\mu \mathrm{g} /$ lane) were chromatographed on glass HPTLC plates (Whatman Inc.) in chloroform/ methanol/water 50:40:10 with $0.05 \% \mathrm{CaCl}_{2}$, with one plate run in parallel for orcinol staining. Plates were dried, dipped for $1 \mathrm{~min}$ in diethyl ether containing $0.5 \%$ polyisobutylmethacrylate, dried, and preincubated in $1 \%$ BSA/PBS for $1 \mathrm{~h}$, and then washed three times in PBS. Radiolabeled bacteria were overlaid $\left(10^{8} \mathrm{cpm}\right.$ total per plate $)$ and the plates were gently rocked for $1 \mathrm{~h}$, washed four times in PBS, and subjected to autoradiography.

Radioimmunoassay and antibody overlay assays. Glycolipids separated on HPTLC were immunostained according to the procedure of Magnani et al. (50) as modified by Kannagi et al. (51). Radioimmunoassays of GSLs immobilized in microtiter wells was performed according to the method of Karlsson (40), with some modifications. Specificities and sources of mAbs are given in Table $I$.

Immunofluorescence staining of vaginal epithelial cells. Vaginal epithelial cells were washed three times in PBS ( $\mathrm{pH} 7.3$ ), counted in a
Table I. Specificities of Monoclonal Antibodies

\begin{tabular}{|c|c|c|}
\hline Antigen & $\begin{array}{l}\text { Monoclonal } \\
\text { antibody }\end{array}$ & Reference \\
\hline Lewis $^{\mathbf{a}}$ & CA3F4 & ATCC \\
\hline $\begin{array}{l}\text { Sialosyl gal- } \\
\text { globoside }\end{array}$ & ID4 & Produced in this laboratory \\
\hline Disialosyl I & NUH2 & Produced in this laboratory (48) \\
\hline A type I, II, III & AH16 & Produced in this laboratory (55) \\
\hline A type III, IV & HH5 & Produced in this laboratory $(56)^{*}$ \\
\hline Rabbit Ia & CRL 1760 & ATCC \\
\hline
\end{tabular}

* mAb HH5 has the same antigenic specificity as mAb MBrl described in the reference.

hemocytometer, and $\sim 3 \times 10^{4}$ cells were resuspended in PBS. Cells were incubated on ice or at room temperature with the primary $\mathrm{mAb}$ or no antibody for $1 \mathrm{~h}$, washed three times in PBS, and incubated with the FITC-conjugated secondary antibody (diluted 1:100) on ice for 30 min. Primary mAbs were undiluted ID4 or one of two control mAbs to unrelated antigens: NUH2 (undiluted) or CRL1760 (ATCC; undiluted). After three additional washes in PBS, stained cells were evaluated in a blinded fashion by examining each field sequentially using fluorescent microscopy then light microscopy. Cells with faint or no staining were scored as unstained and all others were considered positive.

\section{Results}

Binding of E. coli R45 to GSL standards. The binding of metabolically radiolabeled $E$. coli strain $\mathrm{R} 45$ to glycolipid standards separated on HPTLC plates was determined using a broad panel of GSLs with varying carbohydrate moieties as shown in Table II. As predicted from its genotype and phenotype ( $\mathrm{P}$ and F adhesin positive), the bacteria bound to globo-series GSLs containing the minimal pap-binding moiety gal $\alpha 1-4$ gal as well as several of the suggested receptors for the $F$ adhesin, including globoside, gal-globoside, the Forssman antigen, and globo-A and -H. The organism did not bind to GSLs with structures unrelated to the globo-series GSLs, such as B1 (ABH-B antigen on a type 1 core) and the gangliosides asialo GM1 and asialo GM2. In pilot experiments where organisms were grown under conditions that inhibit $\mathbf{P}$ fimbrial expression, binding of several $E$. coli isolates with $\mathrm{P}$ and/or $\mathrm{F}$ phenotypes to GSLs in bacterial overlay assays was minimal or absent. Three wild-type $E$. coli isolates negative for either the $\mathrm{P}$ or the $\mathrm{F}$ phenotypes failed to bind GSLs, confirming published reports of the binding of other phenotypically negative isolates to GSLs in bacterial overlay assays $(30,32)$.

Binding of $E$. coli $R 45$ to glycolipids extracted from vaginal epithelial cells. Total upper- and lower-phase GSLs were extracted from pooled vaginal epithelial cells collected from three groups of healthy college students: 10 nonsecretors ( 8 with a history of recurrent UTI and 2 without), 12 secretors with a history of recurrent UTI, and 18 secretors without recurrent infections. The distribution of $\mathrm{ABO}$ histo-blood group phenotypes among the women in the groups was comparable. $E$. coli strain R45 (isolated from one of the patient's UTIs) was metabolically ${ }^{35} \mathrm{~S}$-labeled and reacted with the total upper- and lower-phase GSLs from each of the three groups of patients in bacterial HPTLC overlay assays. The organism bound to a 
Table II. Binding of Escherichia coli R45 to Glycosphingolipids

\begin{tabular}{|c|c|c|}
\hline Symbol & Structure & Binding \\
\hline $\mathrm{CMH}$ & Glc $\beta 1-1$ cer & - \\
\hline $\mathrm{CDH}$ & Gal $\beta 1-4$ Glc $\beta 1-1$ cer & - \\
\hline CTH & Gal $\alpha 1-4 \mathrm{Gal} \beta 1-4 \mathrm{Glc} \beta 1-1 \mathrm{cer}$ & + \\
\hline Globoside & GalNAc $\beta 1-3$ Gal $\alpha 1-4$ Gal $\beta 1-4$ Glc $\beta 1-1$ cer & + \\
\hline Gal-globoside & Gal $\beta 1-3$ GalNAc $\beta 1-3$ Gal $\alpha 1-4$ Gal $\beta 1-4$ Glc $\beta 1-1$ cer & + \\
\hline Forssman & GalNAc $\alpha 1-3$ Gal $\beta 1-3$ GalNAc $\beta 1-3$ Gal $\alpha 1-4$ Gal $\beta 1-4$ Glc $\beta 1-1$ cer & + \\
\hline Globo-H & (Fuc $\alpha 1-2)$ Gal $\beta 1-3$ GalNAc $\beta 1-3 \mathrm{Gal} \alpha 1-4 \mathrm{Gal} \beta 1-4 \mathrm{Glc} \beta 1-1$ cer & + \\
\hline Globo-A & GalNAc $\alpha 1-3$ (Fuc $\alpha 1-2)$ Gal $\beta 1-3$ GalNAc $\beta 1-3$ Gal $\alpha 1-4$ Gal $\beta 1-4$ Glc $\beta 1-1$ cer & + \\
\hline SGG & NeuAc $\alpha 2-3 \mathrm{Gal} \beta 1-3 \mathrm{GalNAc} \beta 1-3 \mathrm{Gal} \alpha 1-4 \mathrm{Gal} \beta 1-4 \mathrm{Glc} \beta 1-1 \mathrm{cer}$ & + \\
\hline DSGG & NeuAc $\alpha 2-3$ (NeuAc $\alpha 2-6)$ Gal $\beta 1-3$ GalNAc $\beta 1-3$ Gal $\alpha 1-4$ Gal $\beta 1-4$ Glc $\beta 1-1$ cer & + \\
\hline ASGM1 & Gal $\beta 1-3$ GalNAc $\beta 1-4$ Gal $\beta 1-4$ Glc $\beta 1-1$ cer & - \\
\hline ASGM2 & GalNAc $\beta 1-4$ Gal $\beta 1-4$ Glc $\beta 1-1$ cer & - \\
\hline nLc6 & Gal $\beta 1-4 \mathrm{GlcNAc} \beta 1-3 \mathrm{Gal} \beta 1-4 \mathrm{GlcNAc} \beta 1-3 \mathrm{Gal} \beta 1-4 \mathrm{Glc} \beta 1-1 \mathrm{cer}$ & - \\
\hline B1 & Gal $\alpha 1-3$ (Fuc $\alpha 1-2)$ Gal $\beta 1-3 \mathrm{GlcNAc} \beta 1-3 \mathrm{Gal} \beta 1-4 \mathrm{Glc} \beta 1-1 \mathrm{cer}$ & - \\
\hline
\end{tabular}

$\mathrm{CMH}$, ceramide monohexoside; $\mathrm{CDH}$, ceramide dihexoside; $\mathrm{CTH}$, ceramide trihexoside (globotriaosylceramide); globoside, globotetraosylceramide; gal-globoside, galactosyl globoside; SGG, sialosyl gal-globoside; DSGG, disialosyl gal-globoside; ASGM1, asialo GM1; ASGM2, asialo GM2; nLc6, lacto- $N$-norhexaosylceramide; B1, type 1 chain B antigen; Glc, glucose; cer, ceramide; Gal, galactose; GalNAc, $N$-acetylgalaviosamine; Fuc, fucose; NeuAc, neuraminic acid; GlcNAc, $N$-acetylglucosamine.

unique glycolipid band in the total upper-phase GSLs from nonsecretors, which was not seen in GSLs from either group of secretors (data not shown). This experiment was repeated using pooled vaginal cells from 10 nonsecretors and 20 secretors ( 10 with and 10 without a history of recurrent UTI) with identical results. No differences in binding were detected in either experiment when secretors with and without a history of recurrent UTI were compared.

Subsequent experiments were conducted to identify the unique $E$. coli R45-binding GSL band detected in nonsecretors' vaginal epithelial cells. Total upper neutral GSLs and total upper gangliosides were extracted from vaginal epithelial cells pooled in equal quantities from five nonsecretors and nine secretors and reacted with radiolabeled $E$. coli $\mathrm{R} 45$. In total ganglioside fractions from nonsecretors but not from secretors, the organism bound to bands comigrating with SGG and DSGG standards and also reacted with the standards themselves (Fig. $1 A$ ). The total amount of glycolipid placed in each lane was normalized based upon equivalent numbers of cells. As can be seen from the orcinol TLC, the chemical amounts of total upper-phase gangliosides from nonsecretors and secretors are visually comparable (Fig. $1 B$, lanes 8 and 9 ).

In Fig. $1 A, E$. coli $\mathrm{R} 45$ also bound to a band seen in the total upper neutral GSLs from nonsecretors' vaginal epithelial
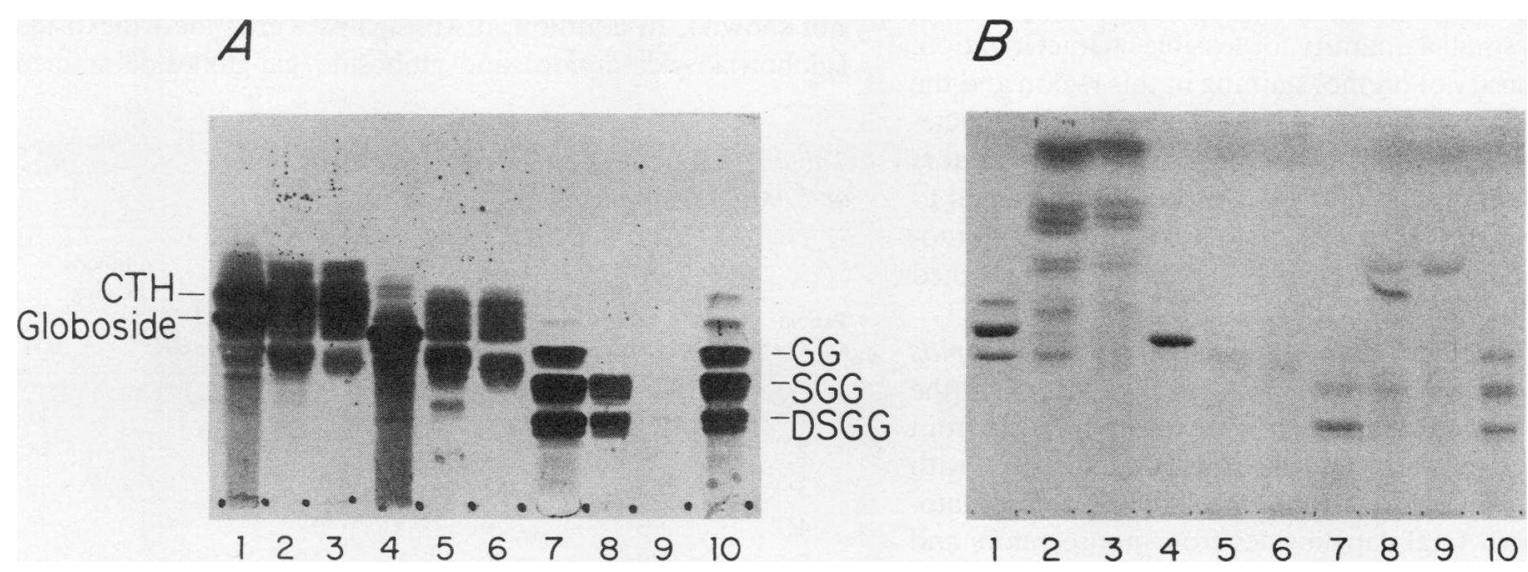

Figure 1. E. coli R45 binding to glycolipids extracted from vaginal epithelial cells. Glycolipids extracted from vaginal epithelial cells were separated on HPTLC plates and overlaid with the metabolically ${ }^{35} \mathrm{~S}$ ] methionine-labeled uropathogenic $E$. coli strain R45 as described in Methods. $A$ shows a representative autoradiogram of bacterial binding to GSLs extracted from equal quantities of pooled vaginal epithelial cells from five nonsecretors and nine secretors and to GSL standards. An orcinol-stained HPTLC of the samples is shown in $B$. Lane 1 contains ceram ide trihexoside (globotriaosylceramide) and globoside standards; lane 2 contains total lower phase GSLs from the nonsecretors; lane 3 contains total lower phase GSLs from the secretors; lane 4 contains the Forssman antigen standard; lanes 5 and 6 contain total upper neutral GSLs from nonsecretors and secretors, respectively; lanes 7 and 10 contain gal-globoside, SGG, and DSGG standards; lanes 8 and 9 contain totai upper phase gangliosides from nonsecretors and secretors, respectively. 


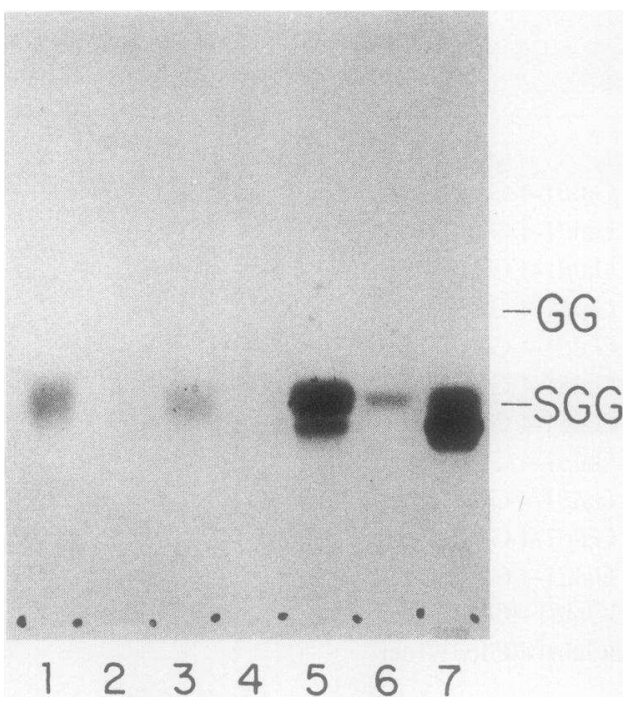

Figure 2. Immunostaining of glycolipids extracted from pooled vaginal epithelial cells of nonsecretors and secretors. Total gangliosides were extracted from vaginal epithelial cells of nonsecretors and secretors pooled in equal quantities and separated on HPTLC plates as described in Methods. Bands from nonsecretors' vaginal epithelial cells that comigrated with SGG and DSGG standards were eluted as described, chromatographed with the total ganglioside fractions and GSL standards, and overlaid with mAb ID4(SGG). Lanes 1 and 2 contain total gangliosides from nonsecretors and secretors, respectively. Lane 3 contains the eluted band from nonsecretors that comigrated with SGG and lane 4 contains the eluted band from nonsecretors that comigrated with DSGG. Lanes 5 and 7 contain SGG standards from human pancreas and lane 6 contains gal-globoside standard from human pancreas (note trace of SGG).

cells (lane 5) but not seen in the total upper neutral GSLs from secretors' cells (lane 6). Although it appears to be unique to nonsecretors, we have not attempted to characterize this moiety, which corresponds to a neutral, extended globo-series GSL (probably extended gal-globoside). The entity appears to be present in too small a quantity for feasible characterization, based on the intensity of orcinol staining in this region and the strength of the signal from bound bacteria. In addition, bacteria bind to lower-phase lipids in a similar fashion in secretors (lane 2) and nonsecretors (lane 3). This binding appeared to be nonspecific and similar to a phenomenon seen in immunostaining experiments (Nudelman and Hakomori, unpublished data).

Immunostaining and radioimmunoassays of glycolipids extracted from pooled vaginal epithelial cells. To confirm the identity of SGG in the total upper ganglioside fraction from nonsecretors' vaginal epithelial cells, bands comigrating with SGG and DSGG were eluted from HPTLC plates, chromatographed along with total gangliosides from nonsecretors and secretors, and reacted with mAb ID4 directed against SGG. As shown in Fig. 2, the mAb stained a band comigrating with SGG in lane $l$, containing the total upper ganglioside fraction from nonsecretors and in lane 3, containing the putative SGG eluted from the nonsecretors. No staining was seen in the total ganglioside fraction from the secretors (lane 2) nor in the putative DSGG material from the nonsecretors (lane 4).

The SGG and DSGG bands from the nonsecretors' vaginal

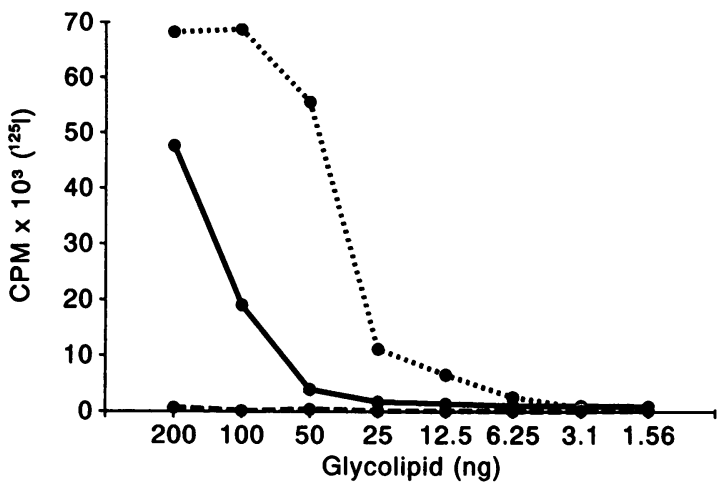

Figure 3. Radioimmunoassay with mAb to sialosyl gal-globoside and glycolipids from nonsecretors. Glycolipid standards and the eluted glycolipid bands comigrating with SGG and DSGG from nonsecretors' vaginal epithelial cells were applied to microtiter wells and subjected to a radioimmunoassay using a monoclonal antibody to SGG (ID4), as outlined in Methods. Dotted line indicates SGG standard from human pancreas; solid line indicates band comigrating with SGG eluted from TLC of nonsecretors' extracted vaginal epithelial cells; dashed line indicates eluted band comigrating with DSGG from nonsecretors and the following GSL standards: gal-globoside and DSGG from human pancreas, GDla from bovine brain, and disialosyl I from human placenta.

epithelial cell extracts were then reacted with ID4 in a radioimmunoassay shown in Fig. 3. The antibody reacted with the SGG band from nonsecretors and with the SGG standard but did not bind to the nonsecretor DSGG band nor to the DSGG, gal-globoside, GDla, or disialosyl I standards.

To determine if the nonsecretor phenotypes of the patients as determined by blood and saliva testing was also expressed in vaginal epithelial cells, total upper-phase GSLs from nonsecretors were chromatographed and reacted with mAbs "anti-Le $\mathrm{a}_{\mathrm{a}}$ " and AH16 (against A type I, II, and III). In the nonsecretor GSLs, a band comigrating with Lewis ${ }^{a}$ standard was brightly stained but no staining was observed with mAb AH16 (data not shown). In addition, mAbs against ceramide trihexoside (globotriaosylceramide) and globoside/gal-globoside stained

Table III. Secretor, Lewis ${ }^{a}$, and ABO Phenotypes and Antibody Binding

\begin{tabular}{rrrrrrr}
\hline $\begin{array}{c}\text { Patient } \\
\text { number }\end{array}$ & $\begin{array}{c}\text { Secretor } \\
\text { phenotype }\end{array}$ & $\begin{array}{c}\text { ABO } \\
\text { phenotype }\end{array}$ & $\begin{array}{c}\text { Lewis } \\
\text { phenotype }\end{array}$ & HH5 & \multicolumn{2}{c}{$\begin{array}{c}\text { Antibody } \\
\text { binding }\end{array}$} \\
\cline { 5 - 7 } 1 & NS & A & + & - & + \\
2 & NS & O & + & - & + \\
3 & NS & O & + & - & + \\
4 & NS & A & + & - & + \\
5 & NS & B & + & - & + \\
6 & S & O & - & - & - \\
7 & S & O & - & - & - \\
8 & S & AB & - & + & - \\
9 & S & AB & - & + & - \\
10 & S & A & - & + & -
\end{tabular}

NS, nonsecretor; S, secretor. 


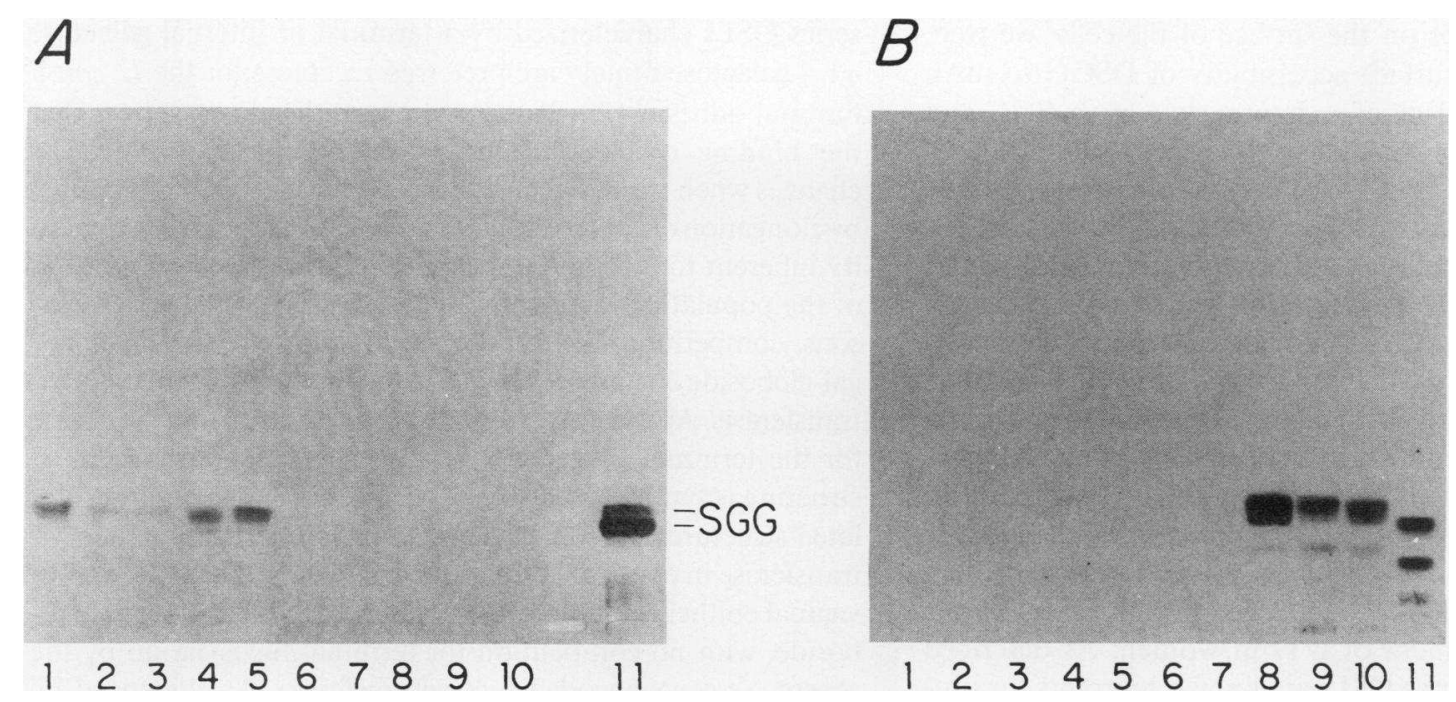

Figure 4. Immunostaining of glycolipids extracted from vaginal epithelial cells of individual nonsecretors and secretors. Total upper phase glycolipids from vaginal epithelial cells of five individual nonsecretors and five individual secretors. ( $10^{7}$ cells/patient) were extracted, chromatographed on HPTLC, and overlaid with $(A)$ mAbs ID4 (SGG) and ( $B)$ HH5 (A type III, IV) as described in Methods. Autoradiographs from antibody overlay assays are shown. Secretor, Lewis ${ }^{a}$, and red blood cell $\mathrm{ABO}$ phenotypes of patients represented in $A$ and $B$ are given in Table III. Lanes $1-10$ contain samples in sequence from patients 1-10. Lane 11 in $A$ contains SGG standard from human pancreas and in $B$ contains upper neutral GSLs from type A human red blood cells.

the cell extracts, confirming that globo-series GSLs are expressed in vaginal epithelial cells (data not shown).

Immunostaining of glycolipids extracted from vaginal epithelial cells from individual patients. To determine whether SGG is found in all nonsecretors (and is absent in all secretors) or present only in some nonsecretors, we extracted total upper and: lower phase GSLs from vaginal epithelial cells collected from five separate nonsecretor individuals as well as from five separate secretor individuals. Equal quantities of cells $\left(10^{7}\right.$ cells per patient) were extracted and chromatographed as described and reacted with antibodies ID4 (against SGG) and HH5 (against A types III and IV). The secretor, ABO, and Lewis ${ }^{a}$ red blood cell phenotypes of the patients (determined by hemagglutination assays) are given in Table III. As shown in Fig. $4 A$, SGG was detected in total upper-phase GSLs from each of the five nonsecretors (lanes 1-5) but not from any of the secretors (lanes 6-10). In Fig. $4 \mathrm{~B}$, mAb HH5 detected A-reactive substances in GSLs from the three secretors with A or $\mathrm{AB}$ phenotypes (lanes 8-10) but not from the nonsecretors (lanes 1-5).

Immunofluorescence assays with native vaginal epithelial cells. To demonstrate that SGG is present and accessible on the surface of native vaginal epithelial cells from nonsecretors but not secretors, immunostaining of cells from two individual secretors and two nonsecretors in three trials using mAb ID4 was compared. As shown in Fig. 5, the majority of nonsecretors' vaginal epithelial cells were stained whereas little or no staining of secretors' cells was observed. Staining of cells from both patient groups with control mAbs NuH2 and CRL1760 (against unrelated antigens) was comparable and minimal.

\section{Discussion}

Several lines of evidence have suggested that the increased susceptibility to recurrent UTI observed in some otherwise healthy women may be explained by genetic factors influencing the density and/or specificity of bacterial receptors available to mediate colonization of their uroepithelial cells (3-8). Although it is known that nonsecretors of histo-blood group antigens are overrepresented among women with a history of recurrent UTIs (5-7) and that uroepithelial cells from nonsecretors show enhanced $E$. coli adherence compared with cells from secretors ( 8), the biochemical basis for these observations has not been clarified. In this study, we have shown that nonsecretors express two unique GSL receptors for $E$. coli R45 on their vaginal epithelial cells, SGG and DSGG, which were not expressed in secretors' vaginal epithelial cells. SGG was accessi-

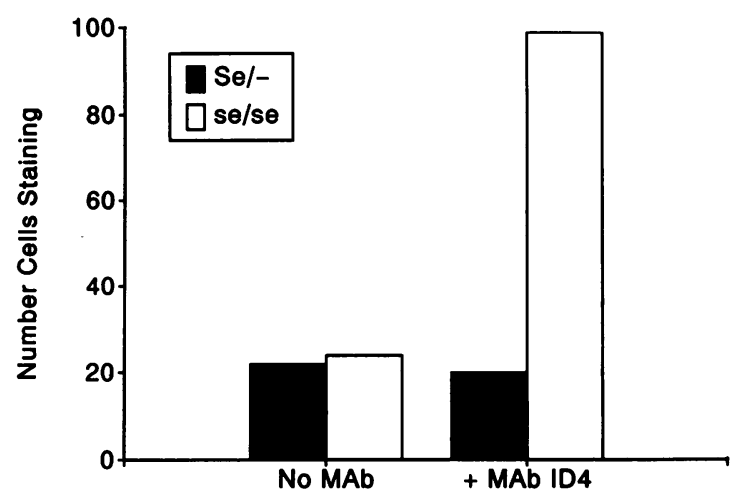

Figure 5. Degree of immunofluorescent staining of vaginal epithelial cells collected from individual nonsecretors and secretors and stained with $\mathrm{mAb}$ to SGG. Immunofluorescence assays performed on vaginal epithelial cells from two secretors and two nonsecretors using $\mathrm{mAb}$ ID4 (against SGG). 50 cells/patient in two assays and 20 cells/patient in one assay were examined and scored for intensity of fluorescent staining. The total number of cells staining in three assays combined are shown. Cells with faint or no staining were considered negative whereas any other degree of staining was considered positive. 
ble to binding by mAbs on the surface of the cells; we were unable to test for the surface accessibility of DSGG to mAb binding because of the lack of an appropriate mAb. SGG and DSGG were detected in extracts of vaginal epithelial cells pooled from a total of 10 nonsecretors and also in cells collected and separately extracted from five additional individuals with the se/se phenotype, suggesting that the expression of this antigen is uniform for nonsecretors. Considering all bacterialbinding experiments using both pooled and individuals' vaginal epithelial cells, we studied a total of 35 secretors' and 15 nonsecretors' epithelial cells. A large epidemiological study would be necessary to confirm the universality of our findings, but our data support the hypothesis that the $S e$ locus controls the expression of $\mathrm{ABO}$ blood group antigen variants of globoseries GSLs in vaginal epithelial cells, an anatomic site which plays an important role in the sequence of colonization events preceding the development of UTI in women. As described above, several globo-series GSLs are known receptors for uropathogenic $E$. coli and are present in other urinary tract sites (20-32, 34, 35), but the influences of the $\mathrm{Se}$ gene on globo-series biosynthesis in vaginal epithelium has not been previously demonstrated to our knowledge. Leffler et al. (52) suggested that globo-series GSL synthesis in voided uroepithelial cells from adults depended on ABO and secretor status. The presence of SGG and DSGG in uroepithelial cells from nonsecretors may account for the increased binding of $E$. coli to their cells and for their increased susceptibility to recurrent UTI.

In addition to supporting the role of a genetic host factor in the pathogenesis of recurrent UTI in women, our data clarify the mechanism by which this occurs. Others have speculated that $E$. coli receptors on uroepithelial cells from nonsecretors are more accessible because of the lack of fucosyltransferasemediated synthesis of $\mathrm{A}, \mathrm{B}$, and $\mathrm{H}$ antigens, whereas in secretors, the presence of histo-blood group antigens on epithelial cells might shield the receptors and prevent bacterial binding $(6,8,53)$. However, reports correlating secretor status with the expression of histo-blood group antigens on type I-IV carbohydrate core structures in the urinary tract are conflicting (54). The correlation of secretor state with expression of $\mathrm{ABH}$ antigens has only been clearly demonstrated for antigens carried on type I chains $(52,54)$, but uropathogenic $E$. coli have not been reported to bind to type I core GSLs (52). This was also true in our study. In GSLs extracted from vaginal epithelial cells from nonsecretors and secretors, respectively, we identified major bands corresponding in TLC migration to Lewis ${ }^{a}$ and Lewis ${ }^{b}$ antigens. In extracts from nonsecretors, the Lewis ${ }^{a}$ band reacted with an $\mathrm{mAb}$ directed to Lewis ${ }^{\mathrm{a}}$. However, $E$. coli $\mathrm{R} 45$ did not bind to either of the Lewis ${ }^{a}$ or Lewis ${ }^{b}$ bands. In contrast, we have shown that on vaginal epithelial cells, there is a correlation between secretor status and expression of well-described receptors for uropathogenic $E$. coli, the type IV chain (globo-series) GSLs. Rather than failing to shield bacterial receptors because of their lack of fucosyltransferase-mediated synthesis of $A, B$, and $H$ antigens on type 1 chains, nonsecretors synthesize unique sialylated, $E$. coli-binding derivatives of the globo-series GSLs. To our knowledge, influences of the $S e$ gene on globo-series biosynthesis in vaginal epithelium have not been previously demonstrated.

Genetic variability in glycosylation encoded by blood group genes is generally thought to be involved in "masking" or shielding glycan receptors for microbial pathogens. Globo- series GSLs characterized by a terminal or internal galactose $\alpha 1-4$ galactose moiety are preferred receptors for the $E$. coli $\mathrm{P}$ fimbrial adhesin (20-28). Previous studies have shown that the binding of P-fimbriated $E$. coli to globo-series GSLs changes when the disaccharide receptor site is further modified by elongation of the saccharide chain (28). The genetic variability inherent to blood group antigens implies that a proportion of the population lacks certain glycan structures. In such persons, competition for terminal glycosylation of the precursor gal-globoside is shared by both a fucosyltransferase and a sialyltransferase. Apparently, the affinity of the fucosyltransferase for the terminal galactose is greater and hence the Globo $\mathrm{H}$ structure is synthesized to the exclusion of any terminally sialylated structures. In contrast, nonsecretors lack such a fucosyltransferase in epithelial cells and synthesize SGG and DSGG in vaginal epithelium through sialylation of the precursor gal-globoside, with no competition for terminal fucosylation by the absent $\mathrm{Se}$ gene-encoded fucosyltransferase. As evidenced by our results, this sialylation does not interfere with the receptor activity of the globo core.

In summary, we have shown that nonsecretors of histoblood group antigens synthesize unique GSLs, SGG and DSGG, on their vaginal epithelial cells, which are not found in cells from secretors. As these moieties serve as receptors for uropathogenic $E$. coli, this finding may be a biochemical explanation for the increased adherence of bacteria to these women's uroepithelial cells and for their propensity to develop recurrent UTIs. However, we have also shown that other globo-series GSLs known to be receptors for uropathogenic $E$. coli are present in GSL extracts from vaginal epithelial cells and bind bacteria in HPTLC overlay assays. In nonsecretors, SGG and DSGG may be more abundant or accessible on vaginal epithelial cells than other $E$. coli receptors or the affinity of bacterial binding for these moieties may be higher than the affinity for other globoseries GSLs. We are presently pursuing studies comparing the relative densities and bacterial binding affinities of the various $E$. coli receptors on vaginal epithelial cells from nonsecretors and secretors to determine the relative contributions of these receptors to the observed differences in bacterial adherence to vaginal epithelial cells from the two patient populations. Finally, our findings may have possible clinical applications. For example, bacterial receptor analogues, perhaps incorporated in a spermicidal preparation, could be applied topically to the vaginal epithelium to inhibit binding of $E$. coli and subsequent development of UTI. We are presently pursuing these possibilities in various patient populations.

\section{Acknowledgments}

We thank Thomas M. Hooton, M.D. for providing patients and helpful suggestions; Carol Winter, R.N. and Lisa Kuwamura for assistance in collecting specimens; and Sharon Baker-Johnson and Dr. Sheila Lukehart for providing assistance with materials for and advice on immunofluorescence assays.

This work was supported in part by Grants DK-40045 and AI07044 from the National Institutes of Health.

\section{References}

1. Mabeck, C. E. 1972. Treatment of uncomplicated urinary tract infection in nonpregnant women. Postgrad. Med. J. 48:69-75.

2. Stamey, T. A., and C. C. Sexton. 1975. The role of vaginal colonization 
with Enterobacteriaceae in recurrent urinary tract infections. J. Urol. 113:214217.

3. Schaeffer, A. J., J. M. Jones, and J. K. Dunn. 1981. Association of in vitro Escherichia coli adherence to vaginal and buccal epithelial cells with susceptibility of women to recurrent urinary-tract infections. N. Engl. J. Med. 304:10621066.

4. Svanborg-Eden, C., and U. Jodal. 1979. Attachment of Escherichia coli to urinary sediment epithelial cells from urinary tract infection-prone and healthy children. Infect. Immun. 26:837-840.

5. Kinane, D. F., C. C. Blackwell, R. P. Brettle, D. M. Weir, F. P. Winstanley, and R. A. Elton. 1982. ABO blood group, secretor state and susceptibility to recurrent urinary tract infection in women. Br. Med. J. 285:7-9.

6. Sheinfeld, J., A. J. Schaeffer, C. Cordon-Cardo, A. Rogatko, and W. R. Fair. 1989. Association of the Lewis blood-group phenotype with recurrent urinary tract infections in women. N. Engl. J. Med. 320:773-777.

7. Hooton, T. M., C. Johnson, P. L. Roberts, and W. E. Stamm. 1989. The association of sex, with or without diaphragm and spermicide use, with UTI. In Program and Abstracts. 29th Intersci. Conf. Antimicrob. Agents Chemother. Proc. 8. (Abstr.)

8. Lomberg, H., B. Cedergren, H. Leffler, B. Nilsson, A.-S. Carlstrom, and C. Svanborg-Eden. 1986. Influence of blood group on the availability of receptors for attachment of uropathogenic Escherichia coli. Infect. Immun. 51:919-926.

9. Stapleton, A., S. Moseley, and W. E. Stamm. 1991. Urovirulence determinants in Escherichia coli isolates causing first-episode and recurrent cystitis in women. J. Infect. Dis. 163:773-779.

10. Arthur, M., C. E. Johnson, R. H. Rubin, R. D. Arbeit, C. Campanelli, C. Kim, S. Steinbach, M. Agarwal, R. Wilkinson, and R. Goldstein. 1989. Molecular epidemiology of adhesin and hemolysin virulence factors among uropathogenic Escherichia coli. Infect. Immun. 57:303-313.

11. Sandberg, T., B. Kaijser, G. Lidin-Janson, K. Lincoln, F. Orskov, I. Orskov, E. Stokland, and C. Svanborg-Eden. 1988. Virulence of Escherichia coli in relation to host factors in women with symptomatic urinary tract infection. $J$. Clin. Microbiol. 26:1471-1476.

12. O'Hanley, P., D. Low, I. Romero, D. Lark, K. Vosti, S. Falkow, and G. Schoolnik. 1985. Gal-gal binding and hemolysin phenotypes and genotypes associated with uropathogenic Escherichia coli. N. Engl. J. Med. 313:414-420.

13. Lidefelt, K.-J., I. Bollgren, G. Kallenius, and S. B. Svenson. 1987. P fimbriated Escherichia coli in children with acute cystitis. Acta Paediatr. Scand. 76:775-780

14. Johnson, J. R., P. L. Roberts, and W. E. Stamm. 1987. P fimbriae and other virulence factors in Escherichia coli urosepsis: association with patients' characteristics. J. Infect. Dis. 156:225-229.

15. Jacobson, S. H., L.-R. Lins, S. B. Svenson, and G. Kallenius. 1985. P fimbriated Escherichia coli in adults with acute pyelonephritis. J. Infect. Dis. 152:426-427.

16. Vaisenen, V., L. G. Tallgren, P. H. Makela, G. Kallenius, H. Hultberg, J. Elo, A. Siitonen, C. Svanborg-Eden, S. B. Svenson, and T. Korhonen. 1981. Mannose-resistant haemagglutination and $\mathrm{P}$ antigen recognition are characteristic of Escherichia coli causing primary pyelonephritis. Lancet 2:1366-1369.

17. Kallenius, G., S. B. Svenson, H. Hultberg, R. Mollby, I. Helin, B. Cedergren, and J. Winberg. 1981. Occurrence of P-fimbriated Escherichia coli in urinary tract infections. Lancet 2:1369-1372.

18. Vaisanen-Rhen, V., J. Elo, E. Vaisanen, A. Siitonen, I. Orskov, F. Orskov, S. B. Svenson, P. H. Makela, and T. K. Korhonen. 1984. P-fimbriated clones among uropathogenic Escherichia coli strains. Infect. Immun. 48:149-155.

19. Westerlund, B., A. Siitonen, J. Elo, P. H. Williams, T. K. Korhonen, and P. H. Makela. 1988. Properties of Escherichia coli isolates from urinary tract infections in boys. J. Infect. Dis. 158:996-1002.

20. Kallenius, G., R. Mollby, S. B. Svenson, J. Winberg, A. Lundblad, S. Svennsson, and B. Cedergren. 1980. The $\mathrm{P}^{\mathrm{k}}$ antigen as receptor for the haemagglutinin of pyelonephritic Escherichia coli. FEMS (Fed. Eur. Microbiol. Soc.) Microbiol. Lett. 7:297-302.

21. Leffler, H., and C. Svanborg-Eden. 1980. Chemical identification of a glycosphingolipid receptor for Escherichia coli attaching to human urinary tract cells and agglutinating human erythrocytes. FEMS (Fed. Eur. Microbiol. Soc.) Microbiol. Lett. 8:127-134.

22. Svanborg-Eden, C., and H. Leffler. 1980. Glycosphingolipids of human urinary tract as possible receptors for adhering Escherichia coli. Scand. J. Infect. Dis. Suppl. 24:144-147.

23. Kallenius, G., R. Mollby, S. B. Svenson, J. Winberg, and H. Hultberg. 1981. Identification of a carbohydrate receptor recognized by uropathogenic Escherichia coli. Infection. 8(Suppl. 3):S288-S293.

24. Kallenius, G., S. B. Svenson, R. Mollby, B. Cedergren, H. Hultberg, and J. Winberg. 1981. Structure of carbohydrate part of receptor on human uroepithelial cells for pyelonephritogenic Escherichia coli. Lancet 2:604-606.

25. Leffler, H., and C. Svanborg-Eden. 1981. Glycolipid receptors for uropathogenic Escherichia coli on human erythrocytes and uroepithelial cells. Infect. Immun. 34:920-929.
26. Kallenius, G., S. B. Svenson, R. Mollby, T. Korhonen, J. Winberg, B. Cedergren, I. Helin, and H. Hultberg. 1982. Carbohydrate receptor structures recognized by uropathogenic Escherichia coli. Scand. J. Infect. Dis. Suppl. 33:5260 .

27. Svenson, S. B., H. Hultberg, G. Kallenius, T. K. Korhonen, R. Mollby, and J. Winberg. 1983. P-fimbriae of pyelonephritogenic Escherichia coli: identification and chemical characterization of receptors. Infection. 11:73/61-79/67.

28. Bock, K., M. E. Breimer, A. Brignole, G. C. Hansson, K.-A. Karlsson, G Larson, H. Leffler, B. E. Samuelsson, N. Stromberg, C. Svanborg-Eden, et al. 1985. Specificity of binding of a strain of uropathogenic Escherichia coli to gal $\alpha$ 1-4 gal-containing glycosphingolipids. J. Biol. Chem. 260:8545-8551.

29. Lund, B., B.-I. Marklund, N. Stromberg, F. Lindberg, K.-A. Karlsson, and S. Normark. 1988. Uropathogenic Escherichia coli can express serologically identical pili of different receptor binding specificities. Mol. Microbiol. 2:255-263.

30. Lindstedt, R., N. Baker, P. Falk, R. Hull, S. Hull, J. Karr, H. Leffler, C. Svanborg-Eden, and G. Larson. 1989. Binding specificities of wild-type and cloned Escherichia coli strains that recognize globo-A. Infect. Immun. 57:33893394

31. Karr, J. F., B. J. Nowicki, L. D. Truong, R. A. Hull, J. J. Moulds, and S. I Hull. 1990. pap-2-encoded fimbriae adhere to the P blood group-related glycosphingolipid stage-specific embryonic antigen 4 in the human kidney. Infect. Immun. 58:4055-4062.

32. Stromberg, N., B.-I. Marklund, B. Lund, D. Ilver, A. Hamers, W. Gaastra, K.-A. Karlsson, and S. Normark. 1990. Host-specificity of uropathogenic Escherichia coli depends on differences in binding specificity to gal $\alpha 1-4$ gal-containing isoreceptors. EMBO (Eur. Mol. Biol. Organ.) J. 9:2001-2010.

33. Breimer, M. E., and P.-A. Jovall. 1985. Structural characterization of a blood group A heptaglycosylceramide with globo-series structure: the major glycolipid based blood group A antigen of human kidney. FEBS (Fed. Eur. Biochem. Soc.) Lett. 179:165-172.

34. Breimer, M. E., G. C. Hansson, and H. Leffler. 1985. The specific glycosphingolipid composition of human ureteral epithelial cells. J. Biochem. 98:1169-1180.

35. Lindstedt, R., G. Larson, P. Falk, U. Jodal, H. Leffler, and C. Svanborg. 1991. The receptor repertoire defines the host range for attaching Escherichia coli strains that recognize globo-A. Infect. Immun. 59:1086-1092.

36. Clausen, H., and S.-I. Hakomori. 1989. ABH and related histo-blood group antigens: immunochemical differences in carrier isotypes and their distribution. Vox Sang. 56:1-20.

37. Kannagi, R., S. B. Levery, and S.-I. Hakomori. 1984. Blood group H antigen with globo-series structure. Isolation and characterization from human blood group O erythrocytes. FEBS (Fed. Eur. Biochem. Soc.) Lett. 175:397-401.

38. Clausen, H., K. Watanabe, R. Kannagi, S. B. Levery, E. Nudelman, Y. Arao-Tomono, and S.-I. Hakomori. 1984. Blood group A glycolipid ( $\left.A^{x}\right)$ with globo-series structure which is specific for blood group $A_{1}$ erythrocytes: one of the chemical bases for $A_{1}$ and $A_{2}$ distinction. Biochem. Biophys. Res. Commun 124:523-529.

39. Hansson, G. C., K.-A. Karlsson, G. Larson, N. Stromberg, and J. Thurin 1985. Carbohydrate-specific adhesion of bacteria to thin-layer chromatograms: a rationalized approach to the study of host cell glycolipid receptors. Anal. Biochem. 146:158-163.

40. Karlsson, K.-A., and N. Stromberg. 1987. Overlay and solid-phase analysis of glycolipid receptors for bacteria and viruses. Methods Enzymol. 138:220 232.

41. Daifuku, R., and W. E. Stamm. 1986. Bacterial adherence to bladder uroepithelial cells in catheter-associated urinary tract infection. N. Engl. J. Med. 314:1208-1213.

42. Folch, J., M. Lees, and G. H. Sloane Stanley. 1957. A simple method for the isolation and purification of total lipides from animal tissues. J. Biol. Chem. 226:497-509.

43. Skipski, V. P. 1975. Thin-layer chromatography of neutral glycosphingolipids. Methods Enzymol. 35:396-425.

44. Clausen, H., M. Stroud, J. Parker, G. F. Springer, and S.-I. Hakomori. 1988. Monoclonal antibodies directed to the blood group A associated structure, galactosyl A: specificity and relation to the Thomsen-Friedenreich antigen. $\mathrm{Mol}$. Immunol. 25:199-204.

45. Hakomori, S., S.-M. Wang, and W. W. Young. 1977. Isoantigenic expression of Forssman glycolipid in human gastric colonic mucosa: its possible identity with "A-like antigen" in human cancer. Proc. Natl. Acad. Sci. USA. 74:30233027.

46. Kannagi, R., S. B. Levery, F. Ishigami, S.-I. Hakomori, L. H. Shevinsky, B. B. Knowles, and D. Solter. 1983. New globoseries glycosphingolipids in human teratocarcinoma reactive with the monoconal antibody directed to developmentally regulated antigen, stage-specific embryonic antigen 3. J. Biol. Chem. 258:8934-8942.

47. Nudelman, E., Y. Fukushi, S. B. Levery, T. Higuchi, and S.-I. Hakomori. 1986. Novel fucolipids of human adenocarcinomas: disialosyl $\mathrm{Le}^{\mathrm{a}}$ antigen (III ${ }^{4} \mathrm{FucIII}{ }^{6} \mathrm{NeuAcIV}^{3} \mathrm{NeuAcLc}_{4}$ ) of human colonic adenocarcinoma and the 
monoclonal antibody (FH7) defining this structure. J. Biol. Chem. 261:54875495.

48. Nudelman, E. D., U. Mandel, S. B. Levery, T. Kaizu, and S. Hakomori 1989. A series of disialogangliosides with binary $2-3$ sialosyllactosamine structure, defined by monoclonal antibody NUH2, are oncodevelopmentally regulated antigens. J. Biol. Chem. 264:18719-18725.

49. Maniatis, T., E. F. Fritsch, and J. Sambrook. 1982. Molecular Cloning: A Laboratory Manual. Cold Spring Harbor Laboratory, Cold Spring Harbor, NY. $545 \mathrm{pp}$.

50. Magnani, J. L., D. F. Smith, and V. Ginsburg. 1980. Detection of gangliosides that bind cholera toxin: direct binding of ${ }^{125}$ I-labeled toxin to thin-layer chromatograms. Anal. Biochem. 109:399-402.

51. Kannagi, R., E. Nudelman, S. B. Levery, and S. Hakomori. 1982. A series of human erythrocyte glycosphingolipids reacting to the monoclonal antibody directed to a developmentally regulated antigen, SSEA-1. J. Biol. Chem. 257:14865-14872.

52. Leffler, H., H. Lomberg, and C. Svanborg Eden. 1989. Glycolipid recep- tors for bacterial adhesion on human urinary tract epithelium: relation to blood group and age. In Host Parasite Interactions in Urinary Tract Infections. E. H. Kass and C. Svanborg-Eden, editors. University of Chicago Press, Chicago. 9399.

53. Schoolnik, G. K. 1989. How Escherichia coli infects the urinary tract. $N$ Engl. J. Med. 320:804-805.

54. Orntorft, T. F., H. Wolf, H. Clausen, S.-I. Hakomori, and E. Dabelsteen. 1988. Blood group ABO-related antigens in fetal and normal adult bladder urothelium: immunohistochemical study of Type 2 chain structures with a panel of mouse monoclonal antibodies. Lab. Invest. 58:576-583.

55. Abe, K., S. B. Levery, and S.-I. Hakomori. 1984. The antibody specific to type 1 chain blood group A determinant. J. Immunol. 132:1951-1954.

56. Bremer, E. G., S. B. Levery, S. Sonnino, R. Ghidoni, S. Canevari, R. Kannagi, and S. Hakomori. 1984. Characterization of a glycosphingolipid antigen defined by the monoclonal antibody $\mathrm{MBr} 1$ expressed in normal and neoplastic epithelial cells of human mammary gland. J. Biol. Chem. 259:14773-14777. 